\title{
Dipodascus starmeri sp. nov., a New Species of Yeast Occurring in Cactus Necroses
}

\begin{abstract}
HERMAN J. PHAFF, ${ }^{1 *}$ JOHN BLUE, ${ }^{1}$ ALLEN N. HAGLER, ${ }^{2}$ AND CLETUS P. KURTZMAN ${ }^{3}$
Department of Food Science \& Technology, University of California, Davis, California $95616^{1}$; Instituto de Microbiologia, Universidade Federal de Rio de Janeiro, Rio de Janeiro, Brazil ${ }^{2}$; and Microbial Properties Research, National Center for Agricultural Utilization Research, USDA Agricultural Research Service, Peoria, Illinois $61604^{3}$

In a previous publication describing the geographic distribution of yeasts associated with cactus necroses (W. T. Starmer, M.-A. Lachance, H. J. Phaff, and W. B. Heed, Evol. Biol. 24:253-296, 1990), 127 isolates were identified as strains of Candida ingens van der Walt et van Kerken on the basis of morphology and certain phenotypic characteristics. Here we show by using DNA hybridization and additional phenotypic properties that these strains were misidentified and that they represent a minimum of three separate species that can be differentiated from $C$. ingens and from each other by utilization of 2-propanol or acetone, sensitivity to digitonin, utilization of $\mathrm{L}$-lysine as a sole nitrogen source, vitamin dependence, $\mathrm{NaCl}$ tolerance, lipolytic activity, and habitat. One of the new species is haploid and heterothallic, and its teleomorph represents the genus Dipodascus. We describe Dipodascus starmeri sp. nov. The phylogenetic relationship of $D$. starmeri with other members of the genus Dipodascus and its anamorph, the genus Geotrichum, was estimated from ribosomal DNA nucleotide sequence divergence. The type strain, a heterothallic haploid isolate, is UCD-FST 72-316 (= CBS 780.96 = ATCC 200546 = NRRL Y-17816). The complementary mating type is UCD-FST 81-513.3 (= CBS 781.96 = ATCC 200547 = NRRL Y-17817).
\end{abstract}

Extensive investigations of the yeast biota found in necrotic tissue of cactus species indigenous to the Americas (13) revealed a significant number of new cactus-specific yeast species, together with a number of species also known from other habitats. One of the predominant species in the latter category was identified as Candida ingens van der Walt et van Kerken by using the determinative keys of the taxonomic treatises edited by Lodder (18) and Kreger-van Rij (8). Identification was based primarily on the utilization pattern of traditional carbon and nitrogen compounds and cell morphology. A reinvestigation of many of the more than 63 strains maintained in our collection by using an expanded metabolic profile, DNA base composition, and DNA hybridization revealed that none of the strains represented $C$. ingens. Further comparisons demonstrated that there were other phenotypic differences as well. $C$. ingens is vitamin independent, grows vigorously in the presence of $10 \% \mathrm{NaCl}$, and is urease positive and lipase negative, whereas the cactus isolates all require vitamins for growth, their maximum $\mathrm{NaCl}$ tolerance level is $5 \%$, and they are urease negative and lipase positive. Most of the other characteristics used routinely in yeast identification (18) were similar, including resistance to cycloheximide.

The present study shows that the isolates from rotting cactus tissue represent a minimum of three separate genomic species that can be differentiated by the following criteria: (i) utilization of L-lysine as a sole nitrogen source; (ii) utilization of 2-propanol or acetone as a sole carbon source; and (iii) sensitivity to digitonin (or triterpene glycosides from cactus species belonging to the subtribe Stenocereinae). One of these new species is haploid and heterothallic with a sexual state characteristic of the genus Dipodascus (1). We propose that this organism should be named Dipodascus starmeri in honor of William T. Starmer because of his extensive contributions to the systematics and ecology of cactus-specific yeasts.

${ }^{*}$ Corresponding author. Phone: (916) 752-1238 or (916) 752-1465. Fax: (916) 752-4759. E-mail: hjphaff@ucdavis.edu.

\section{MATERIALS AND METHODS}

Yeast isolation and identification. Samples of rotting cactus tissue or soil wetted by decomposing columnar cacti were collected in 1971, 1972, 1976, 1981, and 1983 from host plants and locations shown in Table 1. The procedure used for yeast isolation and purification has been described previously (15).

The isolates were characterized phenotypically by methods currently used in yeast taxonomy (17), but additional carbon compounds were used in the assimilation tests; these compounds included hexadecane, D-glucosamine, $N$-acetyl-Dglucosamine, methanol, 2-propanol, acetone, ethyl acetate, butyric acid, hexanoic acid, and octanoic acid. The last seven compounds were tested by adding each of them at a concentration of $1 \%(\mathrm{vol} / \mathrm{vol}$, based on medium volume) to the inverted cover of a flat-bottom petri dish after inoculation of test cultures with a multipoint inoculator on Yeast Nitrogen Base (Difco) agar. The dishes were then sealed with Parafilm M (American Can Co., Greenwich, Conn.) and incubated upside down at $30^{\circ} \mathrm{C}$. Hexadecane was autoclaved in an atomizer for $15 \mathrm{~min}$ at a pressure of $15 \mathrm{lb} / \mathrm{in}^{2}$ and sprayed in a thin layer onto the surface of inoculated Yeast Nitrogen Base agar, and the plates were incubated at $30^{\circ} \mathrm{C}$. The medium used to test for casein hydrolysis has been described previously (9). Lipase activity was tested on solid medium consisting of $1 \%$ peptone, $0.5 \% \mathrm{NaCl}, 0.2 \%$ $\mathrm{CaCl}_{2}, 0.45 \%$ Tween 80 , and $2 \%$ agar. A zone of precipitate surrounding a test colony was used as an indicator of extracellular lipase activity.

Susceptibility to triterpene glycosides or digitonin was tested at 25 and $37^{\circ} \mathrm{C}$ in YM agar plates containing $1 \%$ dried, powdered agria tissue or $8 \mathrm{mg}$ of digitonin per liter, as described by Starmer et al. (12).

Nucleic acid analyses. Nuclear DNA base compositions were determined by using the buoyant density method in $\mathrm{CsCl}$ as described by Price et al. (10), excep that the buoyant density of the Micrococcus luteus reference DNA was calculated to be $1.7310 \mathrm{~g} / \mathrm{cm}^{3}$ rather than $1.7311 \mathrm{~g} / \mathrm{cm}^{3}$. DNA extraction, purification, and reassociation were done by the procedure of Price et al. (10), except that purified DNA was concentrated by electrophoresis in a concentrator (ISCO, Lincoln, Nebr.) and the reference DNA was labeled by using a modified random primed labeling method of Feinberg and Vogelstein $(2,3)$ as described in detail by Lachance et al. (7). dATP, dCTP, dGTP, dTTP, and Klenow enzyme were purchased from Boehringer Mannheim Biochemicals, Indianapolis, Ind $\left.{ }^{32} \mathrm{P}\right] \mathrm{dATP}$ was obtained from Amersham Corp., Arlington Heights, Ill.; and the hexanucleotide primer mixture used was obtained from Pharmacia, Inc., Piscataway, N.J.

The relationship of D. starmeri to other species of the genus Dipodascus and its anamorph, the genus Geotrichum, was determined from a phylogenetic analysis of a ca. 600-nucleotide region at the $5^{\prime}$ end of the large-subunit (26S) rRNA gene. The procedures used for extraction of genomic DNA, amplification by the PCR, and sequence determination with an automated sequencer have been described in detail by Kurtzman and Robnett (6). Histories and the designations of the strains compared have also been given by Kurtzman and Robnett (6) Phylogenetic relationships were determined with the program PAUP version 3.1.1 (16) by using the general heuristic search option followed by bootstrap analysis (100 replications). In the present study, sequences were determined for strains UCD-FST $72-316^{\mathrm{T}}\left(=\right.$ NRRL Y-17816 $\left.{ }^{\mathrm{T}}\right)(\mathrm{T}=$ type strain) and UCD-FST 
TABLE 1. Geographic origins, host plants, and $\mathrm{G}+\mathrm{C}$ contents of nuclear DNAs of representative strains previously classified as $C$. ingens ${ }^{a}$

\begin{tabular}{|c|c|c|c|c|}
\hline Strain $^{b}$ & Species group & $\mathrm{G}+\mathrm{C}$ content $(\mathrm{mol} \%)$ & Host plants or source ${ }^{c}$ & Location \\
\hline UCD-FST 71-149 & B & $39.3 \pm 0.8^{d}$ & Stenocereus thurberi (organ pipe) & Sonora, Mexico \\
\hline UCD-FST 72-107 & $\mathrm{C}$ & $34.6 \pm 0.3$ & Lophocereus schottii (senita) & Sonora, Mexico \\
\hline UCD-FST 72-125 & $\mathrm{C}$ & $34.0 \pm 0.1$ & L. schottii & Sonora, Mexico \\
\hline UCD-FST 72-315 & B & $39.4 \pm 0.2$ & Carnegiea gigantea (saguaro) & Southern Arizona \\
\hline UCD-FST $72-316^{\mathrm{T}}$ & B & $39.4 \pm 0.4$ & C. gigantea & Southern Arizona \\
\hline UCD-FST 72-326 & B & $39.7 \pm 0.6$ & Soil wetted by dripping from $C$. gigantea & Southern Arizona \\
\hline UCD-FST 76-231.2 & B & $39.1 \pm 0.4$ & Stenocereus gummosus (agria) & Baja California, Mexico \\
\hline UCD-FST 76-243.4 & B & $40.0 \pm 0.4$ & S. thurberi & Baja California, Mexico \\
\hline UCD-FST 76-265.3 & B & $39.0 \pm 0.4$ & S. gummosus & Baja California, Mexico \\
\hline UCD-FST 76-276.3 & B & $41.1 \pm 0.4$ & S. gummosus & Baja California, Mexico \\
\hline UCD-FST 76-298.3 & B & $40.1 \pm 0.1$ & S. gummosus & Baja California, Mexico \\
\hline UCD-FST 76-326.2 & $\mathrm{C}$ & $34.3 \pm 0.4$ & L. schottii & Baja California, Mexico \\
\hline UCD-FST 76-350.3 & $\mathrm{C}$ & $34.4 \pm 0.2$ & L. schottii & Baja California, Mexico \\
\hline UCD-FST 76-368.2 & $\mathrm{C}$ & $35.0 \pm 0.2$ & L. schottii & Baja California, Mexico \\
\hline UCD-FST 76-378.2 & $\mathrm{C}$ & $34.5 \pm 0.4$ & Pachycereus pringlei (cardon) & Baja California, Mexico \\
\hline UCD-FST 76-386.2 & $\mathrm{C}$ & $35.0 \pm 0.4$ & L. schottii & Baja California, Mexico \\
\hline UCD-FST 76-394 & $\mathrm{C}$ & $34.9 \pm 0.2$ & L. schottii & Baja California, Mexico \\
\hline UCD-FST $81-513.3$ & B & $39.1 \pm 0.4$ & Opuntia ficus-indica & Tucson, Ariz. \\
\hline UCD-FST 83-930.2 & A & $40.9 \pm 0.7$ & Stenocereus hystrix & Jamaica \\
\hline UCD-FST 83-970.2 & A & $40.3 \pm 0.4$ & S. hystrix & Jamaica \\
\hline UCD-FST $82-465.3$ & A & $39.3 \pm 0.4$ & S. hystrix & Haiti \\
\hline UCD-FST $82-530.4$ & A & $42.0 \pm 0.9$ & S. hystrix & Dominican Republic \\
\hline UCD-FST 83-965.1 & A & $42.1 \pm 0.8$ & S. hystrix & Jamaica \\
\hline C. ingens CBS $4603^{\mathrm{T}}$ & & $38.5 \pm 0.4$ & Winery equipment & South Africa \\
\hline P. humboldtii CBS $6787^{\mathrm{T}}$ & & $38.1 \pm 0.2$ & Mutant of CBS $4603^{\mathrm{T}}$ & \\
\hline
\end{tabular}

${ }^{a}$ See reference 13 .

${ }^{b}$ UCD-FST, Culture Collection of the Department of Food Science \& Technology, University of California, Davis; CBS, Centraalbureau voor Schimmelcultures, Delft, The Netherlands.

${ }^{c}$ The names in parentheses are the common names of cactus species.

${ }^{d}$ Mean \pm standard deviation.

81-513.3 (= NRRL Y-17817), and these sequences were identical. The sequences of the other strains included in the analysis (6) were obtained from the GenBank database.

Nucleotide sequence accession number. The GenBank accession number for the strain UCD-FST $72-316^{\mathrm{T}}$ scquence is GB U59391.

\section{RESULTS}

DNA relatedness studies. As stated above, initial identification of the isolates was based on keys provided in references 8 and 18. Because during a reinvestigation of the isolates several significant differences between $C$. ingens and the cactus isolates were discovered (the latter were vitamin dependent, lipase positive, and urease negative and grew only in media containing up to $5 \% \mathrm{NaCl}$ ), nucleic acid studies were performed to determine whether the cactus isolates were strains of $C$. ingens.

In a preliminary experiment we labeled $C$. ingens $\mathrm{CBS} 4603^{\mathrm{T}}$ and determined its DNA relatedness to two cactus isolates (strains UCD-FST 76-265.3 and UCD-FST 83-970.2) with approximately the same $\mathrm{G}+\mathrm{C}$ content (Table 1 ) from different habitats. In order to have a positive control we included Pichia humboldtii CBS $6787^{\mathrm{T}}$, a mutant of $C$. ingens $\mathrm{CBS} 4603^{\mathrm{T}}$ that was thought to represent the sexual state of $C$. ingens (11). As a negative control we used Trichosporon capitatum CBS 57182. The level of DNA relatedness between $C$. ingens and $P$. humboldtii was $98 \%$, but the level of DNA relatedness between $C$. ingens and the cactus isolates was only $10 \%$ and the level of DNA relatedness between $C$. ingens and $T$. capitatum was $8 \%$. These results demonstrate that the two strains from cactus necroses are not strains of $C$. ingens.

Next, a reverse and more comprehensive experiment was designed, in which strain UCD-FST 76-265.3, a member of the high-G+C-content group (Table 1), was labeled and compared with most of the other strains listed in Table 1. The results are presented in Table 2 .

Six strains showed high DNA relatedness to reference strain UCD-FST 76-265.3, but the other strains from cactus showed low relatedness, while $C$. ingens displayed negligible relative binding. The seven highly related strains were designated provisionally "species B."

Next, we compared strain UCD-FST 83-930.2, a member of the high-G+C-content group (Table 1), with other cactus isolates in a DNA hybridization experiment (Table 2). Four strains showed high DNA relatedness to the reference strain and low relatedness to strains UCD-FST 71-149 and UCDFST 76-265.3, which were used in a previous experiment (Table 2), as well as to $C$. ingens CBS $4603^{\mathrm{T}}$. The five highly related strains, which were provisionally designated "species A," came from necroses in specimens of Stenocereus hystrix on Caribbean islands (Table 1) and represent a species different from species B.

As Table 1 shows, there was a third group of strains among the cactus isolates, which have low $\mathrm{G}+\mathrm{C}$ contents (approximately 34 to $35 \mathrm{~mol} \%$ ). Although it is very unlikely that these strains are members of the same taxon as either of the strains with high $\mathrm{G}+\mathrm{C}$ contents (5), a DNA pairing experiment was performed to confirm this. Strain UCD-FST 76-368.2 was used as the labeled reference strain and compared with other cactus strains (Table 2). All seven strains that exhibited high levels of DNA similarity with the reference strain were members of the low-G+C-content group, whereas species B and species A strains showed low levels of DNA relatedness. This group of strains appears to represent another genospecies, which is referred to provisionally as "species C."

Phenotypic differentiation among the three genospecies. Since so far there were no clear distinguishing characteristics 
TABLE 2. Extents of nuclear DNA reassociation among cactus isolates initially identified as $C$. ingen ${ }^{a}$

\begin{tabular}{|c|c|c|c|}
\hline \multirow{2}{*}{$\begin{array}{c}\text { Strain or reference } \\
\text { DNA }\end{array}$} & \multicolumn{3}{|c|}{ \% Relative binding with labeled DNA from ${ }^{b}$ : } \\
\hline & $\begin{array}{l}\text { Strain UCD- } \\
\text { FST } 83-930.2\end{array}$ & $\begin{array}{l}\text { Strain UCD- } \\
\text { FST 76-265.3 }\end{array}$ & $\begin{array}{l}\text { Strain UCD- } \\
\text { FST } 76-368.2\end{array}$ \\
\hline \multicolumn{4}{|l|}{ Species A } \\
\hline UCD-FST 82-465.3 & 96.3 & & \\
\hline UCD-FST 82-530.4 & 92.8 & & \\
\hline UCD-FST 83-930.2 & 100.0 & 17.1 & \\
\hline UCD-FST 83-965.1 & 103.4 & & \\
\hline UCD-FST 83-970.2 & 98.1 & 24.3 & 7.5 \\
\hline \multicolumn{4}{|l|}{ Species B } \\
\hline UCD-FST 71-149 & 19.9 & 88.3 & \\
\hline UCD-FST $72-315$ & & & \\
\hline UCD-FST $72-316^{\mathrm{T}}$ & & & 9.1 \\
\hline UCD-FST $72-326$ & & & 18.7 \\
\hline UCD-FST 76-231.2 & & 89.6 & \\
\hline UCD-FST 76-243.4 & & 98.8 & \\
\hline UCD-FST 76-265.3 & 23.2 & 100.0 & 9.0 \\
\hline UCD-FST 76-276.3 & & 100.9 & \\
\hline UCD-FST 76-298.3 & & 95.8 & \\
\hline UCD-FST $81-513.3$ & & 92.2 & \\
\hline \multicolumn{4}{|l|}{ Species C } \\
\hline UCD-FST 72-107 & & & 99.1 \\
\hline UCD-FST $72-125$ & & & 99.2 \\
\hline UCD-FST 76-326.2 & & 7.2 & 101.4 \\
\hline UCD-FST 76-350.3 & & 5.8 & 104.7 \\
\hline UCD-FST 76-368.2 & & 2.0 & 100.0 \\
\hline UCD-FST 76-378.2 & & 4.4 & 103.1 \\
\hline UCD-FST 76-386.2 & & 5.7 & 96.1 \\
\hline UCD-FST 76-394 & & & 104.8 \\
\hline C. ingens CBS $4603^{\mathrm{T}}$ & 4.3 & & \\
\hline Calf thymus DNA & 1.3 & & \\
\hline
\end{tabular}

${ }^{a}$ See Table 1 for the origins of the strains used.

${ }^{b}{ }^{32} \mathrm{P}$-labeled DNA $(0.2 \mu \mathrm{g})$ and unlabeled DNA $(200 \mu \mathrm{g})$ were incubated at 62.7 to $63.2^{\circ} \mathrm{C}$ for $25 \mathrm{~h}$ in $0.5 \mathrm{ml}$ of $280 \mathrm{mM}$ phosphate buffer $(\mathrm{pH} 6.8$ ). The values are the averages of the values from three determinations and are corrected for zero-time binding and for self-renaturation (10)

for the three species, we tested additional carbon and nitrogen compounds for assimilatory reactions and found that the following characteristics could be used for differentiation: species $\mathrm{B}$ assimilates L-lysine as a sole $\mathrm{N}$ source and 2-propanol as a sole $\mathrm{C}$ source; species A does not assimilate L-lysine, but assimilates 2-propanol; and species C does not assimilate L-lysine or 2-propanol. The species that assimilate 2-propanol also assimilate acetone as a sole carbon source.

Heterothallism among the strains of species $\mathbf{B}$. Since it was possible that the strains represented haploid mating types, they were mixed in various combinations, plated on McClary's acetate agar (17), and incubated at $30^{\circ} \mathrm{C}$. While individual strains showed no evidence of sporulation, certain mixed combinations produced zygotes and then exhibited ascosporulation. Three strains (UCD-FST 72-315, UCD-FST $72-316^{\mathrm{T}}$, and UCD-FST 72-326) that fit the metabolic pattern of species B all mated with various strains of species B established by DNA hybridization (Table 2). The distribution of mating types is given in Table 3 .

The sexual state of species B is characteristic of the genus Dipodascus Lagerheim (Saccharomycetales: Dipodascaceae) (4). We propose that species B should be named Dipodascus starmeri in honor of W. T. Starmer because of his extensive contributions to the ecology and systematics of cactus-specific yeasts.

Latin description of Dipodacus starmeri. Gametangia inter UCD-FST $72-316^{\mathrm{T}}$ et UCD-FST $81-513.3$ formata ex cellulis
TABLE 3. Strains of D. starmeri previously classified as $C$. ingens and reidentified in this study

\begin{tabular}{lccc}
\hline \multicolumn{1}{c}{ Strain $^{a}$} & $\begin{array}{c}\text { G+C content } \\
(\text { mol\% })\end{array}$ & $\begin{array}{c}\text { \% DNA } \\
\text { complementarity } \\
\text { with strain UCD- } \\
\text { FST 76-265.3 }\end{array}$ & $\begin{array}{c}\text { Mating } \\
\text { type }\end{array}$ \\
\hline UCD-FST 76-265.3 & 39.0 & $100^{b}$ & $\mathrm{~h}^{+}$ \\
UCD-FST 76-231.2 & 39.1 & 90 & $\mathrm{ND}^{c}$ \\
UCD-FST 76-276.3 & 41.1 & 101 & $\mathrm{~h}^{+}$ \\
UCD-FST 76-298.3 & 40.1 & 96 & $\mathrm{~h}^{-}$ \\
UCD-FST 76-243.4 & 40.0 & 99 & $\mathrm{ND}^{-}$ \\
UCD-FST 81-513.3 & 39.1 & 92 & $\mathrm{~h}^{+}$ \\
UCD-FST 71-149 & 39.3 & 88 & $?^{d}$ \\
UCD-FST 72-315 & 39.4 & & $\mathrm{~h}^{+}$ \\
UCD-FST 72-316 & 39.4 & & $\mathrm{~h}^{-}$ \\
UCD-FST 72-326 & 39.7 & $\mathrm{~h}^{+}$ \\
\hline
\end{tabular}

See Table 1 for isolation sources and locations.

${ }^{b}$ Value for labeled reference strain.

$c \mathrm{ND}$, not determined.

${ }^{d}$ Mating reaction questionable.

${ }^{e}$ Strain identified by phenotype and mating reaction.

discretis forma variabilibus; asci globosi, 2-3 ascosporas continentes; ascorum parietes irregulariter dissolventes, sporas in massa conhaerente liberantes. Ascosporae hyalinae, ellipsoideae, strato mucilaginoso persistente. In YM (Difco) liquido post dies 4 ad $30^{\circ} \mathrm{C}$, pellicula sicca, non nitida, tenuis, sursum repens formatur; cellulae ovoideae, elongatae, cylindricae, pyriformes, claviformes, $2.5-6.2 \times 6.5-21 \mu \mathrm{m}$ (interdum $30 \mu \mathrm{m}$ ), hyphae modice constrictum ad septa simplices vel irregulariter ramosae, subinde saepe in arthroconidia disarticulatae. Coloniae post dies 8 in agaro $\mathrm{YM}$ ad $30^{\circ} \mathrm{C} 14$ $\mathrm{mm}$ in diametro. Cultura in agaro malti post dies 8 ad $30^{\circ} \mathrm{C}$ convexa, glabra, non nitida, butyrosa, grisea vel testacea margo lobata discreta. Qualitates physiologicae in tabella collectae. Typus vivus UCD-FST 72-316 (= CBS $780.96=$ ATCC $200546=$ NRRL Y-17816) isolatus ex tabidosus sacculis cacti Carnegiea gigantea isolata est; isotypus vivus UCD-FST 81 513.3 (= CBS $781.96=$ ATCC $200547=$ NRRL Y-17817) isolatus ex tabidosis sacculis cacti Opuntia ficus-indica isolata est.

Description of the type strain of Dipodacus starmeri sp. nov. Dipodascus starmeri (star'me.ri. L. masc. adj. starmeri, of Starmer, honoring W. T. Starmer, a yeast geneticist and biologist). In YM (Difco) liquid medium after 4 days at $30^{\circ} \mathrm{C}$ the cells are ovoid, elongate, cylindrical, pear shaped, and club shaped, are arranged in chains of 4 to about 12 cells, are moderately branched, and are somewhat constricted at the septa; chains tend to break up into arthroconidia. Budding occurs polarly or on broad shoulders on a broad base. The cells are 2.5 to $5.0 \mu \mathrm{m}$ (occasionally $6.2 \mu \mathrm{m}$ ) wide by 6.5 to $21 \mu \mathrm{m}$ (occasionally $30 \mu \mathrm{m}$ ) long. A thin, dull, smooth, creeping pellicle and a sediment develop. Colonies on $\mathrm{YM}$ agar at $30^{\circ} \mathrm{C}$ reach a diameter of $14 \mathrm{~mm}$ after 8 days. A streak culture on malt agar after 2 weeks at $30^{\circ} \mathrm{C}$ is convex, smooth without an aerial mycelium, semidull, butyrous, and greyish to tan with an entire to lobate border. The type strain is haploid and heterothallic; ascospores develop after 3-day-old cells grown on YM agar are mixed with cells of the complementary mating isotype on acetate agar at $30^{\circ} \mathrm{C}$. Two separate cells of opposite mating types produce conjugation tubes (Fig. 1a), which fuse and swell to an ovoid shape, the zygote, which receives most of the contents of the conjugating cells (Fig. 1b), which then appear empty. Meiosis and development of ascospores (two or three spores per ascus) occur immediately afterward (Fig. 1b 


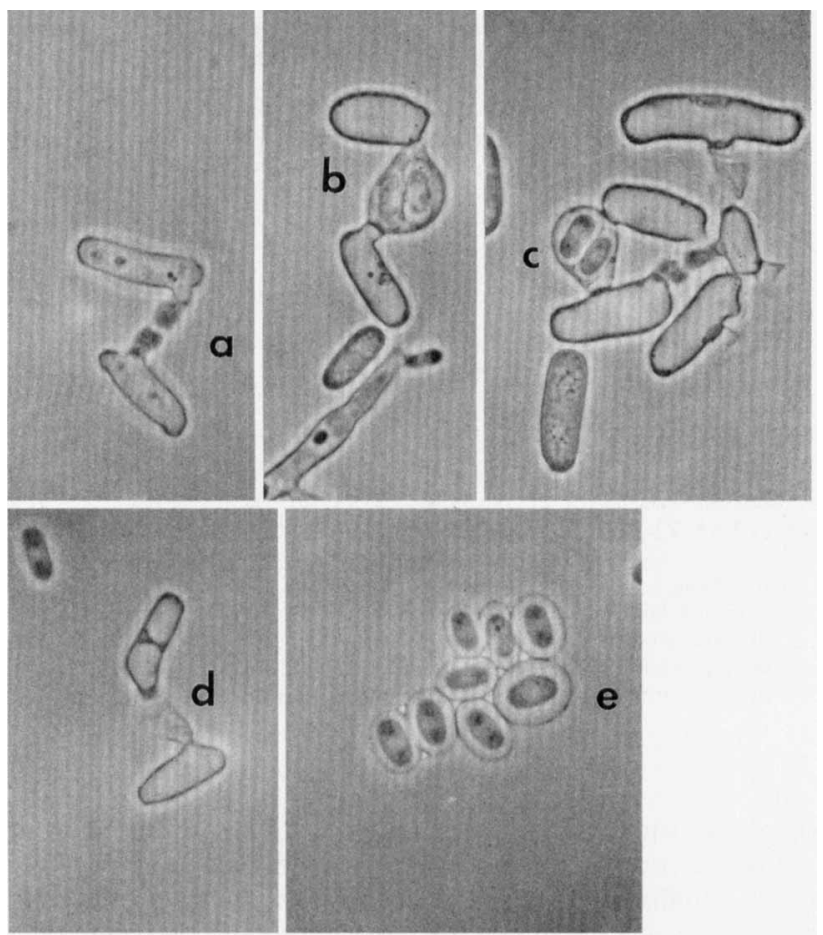

FIG. 1. Sporulation of $D$. starmeri. Ascospores develop after 3-day-old cells of opposite mating types grown on YM agar are mixed on acetate agar at $30^{\circ} \mathrm{C}$ Cells of opposite mating types produce conjugation tubes (a), which fuse and swell to an ovoid shape, the zygote, which receives most of the contents of the conjugating cells (b). Meiosis and development of ascospores follow immediately (b and c). Asci lyse rapidly (d), releasing the spores, which tend to aggregate in masses (e).

and c). Asci lyse rapidly (Fig. 1d), releasing the spores, which tend to aggregate in masses (Fig. 1e). The spores are ovoid to slightly elongate and approximately 2.5 by $5 \mu \mathrm{m}$ and are surrounded by a gelatinous sheath (Fig. 1e).

Glucose is not fermented.

The following carbon compounds are assimilated: glucose, D-galactose, L-sorbose (latent), ethanol, glycerol, lactate, succinate, 2-propanol, acetone (latent), ethyl acetate, octanoic acid, and decanoic acid.

Not assimilated are maltose, sucrose, cellobiose, trehalose, lactose, melibiose, raffinose, melezitose, raffinose, inulin, soluble starch, D-xylose, L-arabinose, D-arabinose, D-ribose, L-rhamnose, i-erythritol, ribitol, galactitol, D-mannitol, D-glucitol, $\alpha$-methyl-D-glucoside, salicin, gluc- $\partial$-lactone, 2-keto-D-gluconate, 5-keto-D-gluconate, citrate, D-gluconate, i-inositol, methanol, D-glucosamine, $N$-acetyl-D-glucosamine, hexadecane, butyric acid, and hexanoic acid.

$\mathrm{KNO}_{3}$ and $\mathrm{KNO}_{2}$ are not utilized as sole sources of nitrogen.

Ammonium ion, L-lysine, cadaverine, and ethyl amine (latent, weak) are utilized.

Growth occurs in amino acid-free medium.

Growth does not occur in vitamin-free medium.

Growth in the presence of triterpene glycosides or digitonin $(8 \mathrm{mg} /$ liter $)$ is moderate at $25^{\circ} \mathrm{C}$ and good at $37^{\circ} \mathrm{C}$.

Growth occurs in the presence of $100 \mu \mathrm{g}$ of cycloheximide per ml.

Growth on $\mathrm{YM}$ agar containing $5 \% \mathrm{NaCl}$ is latent and weak; growth does not occur in the presence of $7.5 \% \mathrm{NaCl}$.

No growth occurs in the presence of $50 \%$ glucose.

Casein and gelatin are not hydrolyzed.
Lipolytic activity is strong.

Urease activity is absent.

Acid is not produced on chalk agar.

Good growth occurs at $45^{\circ} \mathrm{C}$.

The Diazonium Blue $\mathrm{B}$ reaction is negative.

The coenzyme $\mathrm{Q}$ system has nine isoprene units in the side chain.

The $\mathrm{G}+\mathrm{C}$ content of the nuclear DNA of the type strain is $39.4 \mathrm{~mol} \%$, and the $\mathrm{G}+\mathrm{C}$ content of the isotype strain is 39.1 mol\% (Table 1).

Strains of $D$. starmeri occur in necrotic tissue of the columnar cactus species Stenocereus gummosus (agria) and Stenocereus thurberi (organ pipe) in Baja California and Sonora, Mexico, in Carnegiea gigantea (saguaro) in southern Arizona, and (more rarely) in Opuntia ficus-indica in southern Arizona.

The type strain is UCD-FST 72-316 (= CBS 780.96 = ATCC $200546=$ NRRL Y-17816), which was isolated from a rotting saguaro plant in southern Arizona; the isotype strain is UCDFST 81-513.3 (= CBS $781.96=$ ATCC $200547=$ NRRL $\mathrm{Y}-17817)$, which was isolated from a rotting cladode of $O$. ficus-indica near Tucson, Ariz. A summary of the strains identified as $D$. starmeri in this study is given in Table 3 .

Phylogenetic relatedness of $\boldsymbol{D}$. starmeri. The phylogenetic relationship of $D$. starmeri with other members of the Dipodascus clade is shown in Fig. 2. Of the 618 nucleotides sequenced (approximately corresponding to large-subunit positions 63 to 680 of Saccharomyces cerevisiae), there were 276 variable sites, and 195 of these variable sites were phylogenetically informative. A phylogenetic analysis implemented by using the heuristic search option of PAUP found two equally parsimonious trees of 637 steps (consistency index, 0.648 ; retention index, 0.770). The alternate analyses used were a heuristic search with random addition sequence and a branch-andbound search. The tree topologies were essentially identical in all analyses. On the basis of this analysis, $D$. starmeri was found to be a member of the well-supported (bootstrap value, 100\%) Dipodascus ingens clade. The placement of $D$. starmeri near $D$. ingens is less well supported (bootstrap value, 53\%) because there is little nucleotide divergence between the two species, which limits phylogenetic resolution. Other noteworthy relationships include the apparent conspecificity between Dipodascus ambrosiae and Dipodascus ovetensis, among Dipodascus capitatus, Dipodascus specifer, and Geotrichum clavatum, and between Dipodascus armillariae and "Endomyces decipiens" (6).

\section{DISCUSSION}

This study was concerned with a reinvestigation of yeast strains obtained from cactus necroses that were originally thought to represent strains of $C$. ingens van der Walt et van Kerken. A sexual state of this species, designated $P$. humbold$t i i$, was thought to be induced by treating $C$. ingens with a mutagen (11). However, Rodrigues de Miranda subsequently found that $C$. ingens is heterothallic, and ascosporulation was obtained by mixing two complementary strains of this species (1); the sexual state was named $D$. ingens. Our reinvestigation of the cactus isolates in which DNA hybridization and comparison with $C$. ingens were used proved that none of the cactus isolates represented this species, but instead represented three or more separate species. It was later found that the cactus isolates could also be differentiated from $C$. ingens by their strong lipolytic activity, vitamin dependence, low $\mathrm{NaCl}$ toler- 


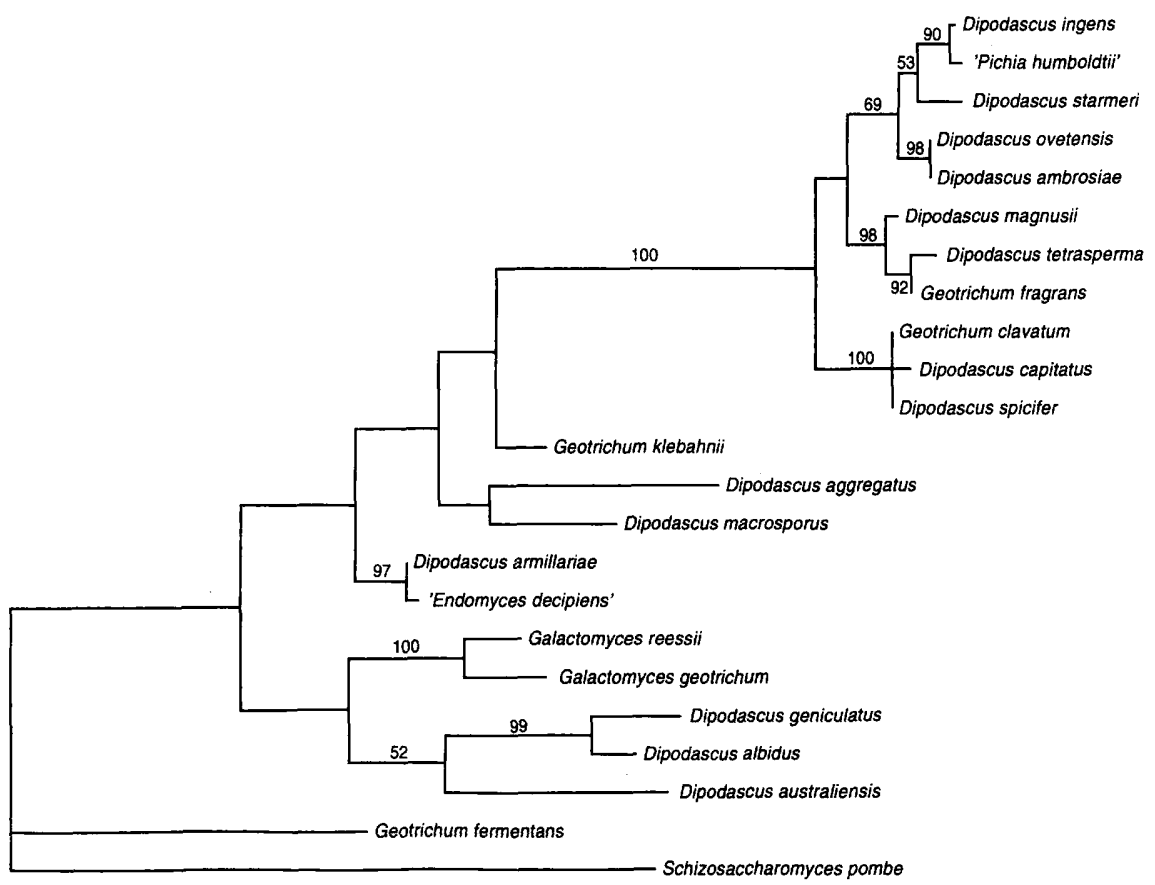

FIG. 2. Phylogenetic tree derived from a maximum-parsimony analysis, depicting the relationship of $D$. starmeri with other members of the Dipodascus-Geotrichum clade. Branch lengths are proportional to number of nucleotide differences, and the numbers on the branches are the frequencies (expressed as percentages) with which the branches appeared in 100 bootstrap replicates. Values are not given for branches with frequencies of less than $50 \%$.

ance, and higher maximum temperature for growth. One of the species (species B) was shown to be heterothallic, its teleomorph fit the description of the genus Dipodascus, and it is described here as $D$. starmeri. Phylogenetic analysis of nucleotide sequences from the $5^{\prime}$ ends of large-subunit ribosomal DNAs showed that $D$. starmeri is closely related to $D$. ingens. Further work is in progress to determine the teleomorphic states of species $\mathrm{A}$ and species $\mathrm{C}$.

Strains of D. starmeri were found only in a geographic area that included Baja California and Sonora in Mexico and southern Arizona, all of which are in the North American Sonoran Desert (13). Most strains came from columnar cacti belonging to the subtribe Stenocereinae, which is characterized by high levels of triterpene glycosides; however, others were isolated from saguaro cactus (a member of the Pachycereinae) and one strain came from an Opuntia species, neither of which contains triterpene glycosides. Since all strains of $D$. starmeri were resistant to these potent toxic compounds at $25^{\circ} \mathrm{C}(12)$, we postulate that the original habitat of $D$. starmeri is in Stenocereus spp., from which it may be transported occasionally to species of other cactus genera by various insects (14).

Two other species of the genus Dipodascus from cactus necroses are known, Dipodascus australiensis v. Arx et Barker and Dipodascus spicifer de Hoog, Smith, et Guého (1). The former, which was isolated from Opuntia stricta in Australia, differs from $D$. starmeri by being homothallic, forming extensive septate mycelia, aerial hyphae, and arthroconidia, producing up to 20 ascospores per ascus, and assimilating D-xylose, D-mannitol, and D-glucitol. The latter species, which was isolated from Opuntia phaeacantha in Arizona, is homothallic, assimilates $\mathrm{D}$-xylose and $\beta$-glucosides, and has a DNA base composition of $30.6 \mathrm{~mol} \% \mathrm{G}+\mathrm{C}$ (nearly $10 \mathrm{~mol} \%$ lower than the $\mathrm{G}+\mathrm{C}$ content of $D$. starmeri).

\section{ACKNOWLEDGMENTS}

We are indebted to Yuzo Yamada for determining the type of coenzyme $Q$ and to Christie J. Robnett for technical assistance with ribosomal DNA sequencing.

\section{REFERENCES}

1. de Hoog, G. S., M. T. Smith, and E. Guého. 1986. A revision of the genus Geotrichum and its teleomorphs. Stud. Mycol. 29:1-131.

2. Feinberg, A. P., and B. Vogelstein. 1983. A technique for radiolabeling DNA restriction endonuclease fragments to high specific activity. Anal. Biochem. 132:6-13.

3. Feinberg, A. P., and B. Vogelstein. 1983. A technique for radiolabeling DNA restriction endonuclease fragments to high specific activity. Addendum Anal. Biochem. 137:266-267.

4. Kurtzman, C. P. Discussion of teleomorphic and anamorphic ascomycetous yeasts and a key to genera. In C. P. Kurtzman and J. W. Fell (ed.), The yeasts: a taxonomic study, 4th ed., in press. Elsevier Science Publishers B.V. Amsterdam, The Netherlands.

5. Kurtzman, C. P., and H. J. Phaff. 1987. Molecular taxonomy, p. 63-94. In A. H, Rose and J. S. Harrison (ed.), The yeasts, 2nd ed., vol. 1. Biology of yeasts. Academic Press, London, United Kingdom

6. Kurtzman, C. P., and C. J. Robnett. 1995. Molecular relationships among hyphal ascomycetous yeasts and yeastlike taxa. Can. J. Bot. 73(Suppl. 1) S824-S830.

7. Lachance, M.-A., W. T. Starmer, and H. J. Phaff. 1990. Metschnikowia hawaiiensis sp. nov., a heterothallic haploid yeast from Hawaiian morning glory and associated drosophilids. Int. J. Syst. Bacteriol. 40:415-420.

8. Meyer, S. A., D. G. Ahearn, and D. Yarrow. 1984. Candida Berkhout, p. 585-844. In N. J. W. Kreger-van Rij (ed.), The yeasts: a taxonomic study, 3rd ed. Elsevier Science Publishers B.V., Amsterdam, The Netherlands.

9. Phaff, H. J., W. T. Starmer, M.-A. Lachance, and P. F. Ganther. 1994 Candida caseinolytica sp. nov., a new species of yeast occurring in necrotic tissue of Opuntia and Stenocereus species in the southwestern United States and Baja California, Mexico. Int. J. Syst. Bacteriol. 44:641-645.

10. Price, C. W., G. B. Fuson, and H. J. Phaff. 1978. Genome comparison in yeas systematics: delimitation of species within the genera Schwanniomyces, Saccharomyces, Debaryomyces, and Pichia. Microbiol. Rev. 42:161-193.

11. Rodrigues de Miranda, L., and T. Török. 1976. Pichia humboldtii sp. nov., the perfect state of Candida ingens. Antonie van Leeuwenhoek 42:343-348.

12. Starmer, W. T., H. W. Kircher, and H. J. Phaff. 1980. Evolution and speciation of host plant specific yeasts. Evolution 34:137-146. 
13. Starmer, W. T., M.-A. Lachance, H. J. Phaff, and W. B. Heed. 1990. The biogeography of yeasts associated with decaying cactus tissue in North America, the Caribbean, and northern Venezuela. Evol. Biol. 24:253-296.

14. Starmer, W. T., H. J. Phaff, J. M. Bowles, and M.-A. Lachance. 1988. Yeasts vectored by insects feeding on decaying saguaro cactus. Southwest. Nat. 33:362-363.

15. Starmer, W. T., and H. J. Phaff. 1983. Analysis of the community structure of yeasts associated with the decaying stems of cactus. II. Opuntia species. Microb. Ecol. 9:247-259,
16. Swofford, D. L. 1993. PAUP: phylogenetic analysis using parsimony, version 3.1.1. Illinois Natural History Survey, Champaign.

17. van der Walt, J. P., and D. Yarrow. 1984. Methods for the isolation, main tenance, classification and identification of yeasts. p. 45-104. In N. J. W. Kreger-van Rij (ed.), The yeasts: a taxonomic study, 3rd ed. Elsevier Science Publishers B.V., Amsterdam, The Netherlands.

18. van Uden, N., and H. Buckley. 1970. Candida Berkhout, p. 893-1087. In J. Lodder (ed.), The yeasts: a taxonomic study, 2nd ed. North Holland Publishing Co., Amsterdam, The Netherlands. 